enorden

\title{
7 NORDISKA
} BERÄTTELSER 


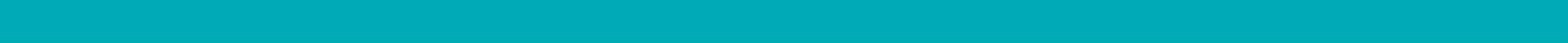




\section{O norden}

\section{NORDISKA BERÄTTELSER}

FÖRORD

Catwalken - en ny arena för nordisk hållbarhetspolitik 7

Debatt om gränshinder ger ny plattform för det nordiska

Bæredygtig business - når erhvervslivet udfordrer politikerne

Da børnelitteraturen fik sit blå stempel

Påträngande omvärld skapar nordisk enighet 
ISBN: 978-92-893-2491-5

http://dx.doi.org/10.6027/ANP2013-721

ANP 2013:721

(C) Nordiska ministerrådet

Redaktör: Bodil Tingsby

Redaktion: Anita Skoglund, Jesper Schou-Knudsen, Bodil Tingsby,

Heidi Orava, Louise Hagemann, Karin Arvidsson, Michael Funch

Layout: Jette Koefoed

Omslag: Jette Koefoed

Bilder:

Sid. 6-8: Benjamin Suomela/norden.org

Sid. 11-12: ImageSelect

Sid. 13: Karin Beate Nøsterud; Johan Wessman/norden.org

Sid.. 14-17: ImageSelect; www.nordic built.org

Sid. 18-21: Johannes Jansson/norden.org; ImageSelect

Sid. 22-23: Johannes Jansson/norden.org

Sid. 25-27: Vita Thomsen/norden.org; Ane Cecilie Blichfeldt /norden.org;

Johannes Jansson/norden.org

Tryck: Rosendahls - Schultz Grafisk

Upplaga: 1200

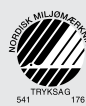

Printed in Denmark

\section{Nordiska ministerrådet \\ Ved Stranden 18 \\ DK-1061 København K \\ Telefon (+45) 33960200 \\ Nordiska rådet \\ Ved Stranden 18 \\ DK-1061 Copenhagen $\mathrm{K}$ \\ Telefon (+45) 33960400}

\section{Det nordiska samarbetet}

Det nordiska samarbetet är ett av världens mest omfattande regionala samarbeten. Det omfattar Danmark, Finland, Island, Norge och Sverige samt Färöarna, Grönland och Åland.

Det nordiska samarbetet är politiskt, ekonomiskt och kulturellt förankrat och är en viktig partner i europeiskt och internationellt samarbete. Den nordiska gemenskapen arbetar för ett starkt Norden i ett starkt Europa.

Det nordiska samarbetet ska stärka nordiska och regionala intressen och värderingar i en global omvärld. Gemensamma värderingar länderna emellan bidrar till att stärka Nordens ställning som en av världens mest innovativa och konkurrenskraftiga regioner. 


\section{FÖRORD}

Det du nu håller i din hand är Sju berättelser om det nordiska samarbetet 2012. Bara sju av tusentals som skulle kunna berättas, men sju som verkligen visar på samarbetets höjd, bredd, uthållighet och betydelse för var och en i Norden. Ibland berörs människor tämligen omgående av det vi gör. Som när Nordiska rådet inför 2012 beslutade om att öppna för möjligheten till något man kallade företräde till rådets utskott. Den möjligheten tog de danska entusiasterna inom Nordic Fashion Association vara på med en önskan om draghjälp för sina idéer om hållbart mode. Och bara några månader senare, på Sessionen i Helsingfors i oktober, stegade modellerna fram på en uppmärksammad Catwalk i Finlands riksdags anrika lokaler.

Mediernas många reportage om människor som berörs negativt av till synes onödiga hinder mellan våra nordiska länders gränser blev en tydlig spegel av hur mycket årets gränshinderdebatter kom att betyda. Det var ett unikt initiativ som ledde till att problemet debatterades i samtliga nordiska parlament under april månad.

En hel bransch kom på fötter när Nordiska ministerrådet en råkall dag i februari kallade till diskussion om möjligheten att skapa nya standarder för ett hållbart byggande. Hundra verksamheter med starka företrädare i spetsen har redan slutit upp och engagerat sig för att göra hållbarheten till ett verktyg för ökad konkurrenskraft.

Ibland kan vägen från ax till limpa kännas längre. Som när beslutet om ett nordiskt barnlitteraturpris fattades - till slut. Eller som när Sverige och Finland under Sessionen offentliggjorde ambitionen att hjälpa Norge att vaka över isländskt luftterritorium. Det var ett konkret bevis på det allt starkare utrikes-, försvars- och säkerhetspolitiska samarbetet i Norden. En fråga som diskuterats sedan 1800-talet.

Svåra frågor måste få ta tid. En annan sådan är den om våra välfärdssamhällens förmåga att inkludera människor som bryter mot normen. På uppdrag av de nordiska kulturministrarna såg vi till att det blev ett hett ämne som skapade debatt på Nordens största bokmässa i Göteborg.

Till den som tycker att det händer för lite i Norden rekommenderar vi Nordisk statistisk årsbok. Den firade 50 år 2012, och i dessa våra Sju berättelser reflekterar vi över en både enastående och delvis överraskande utveckling.

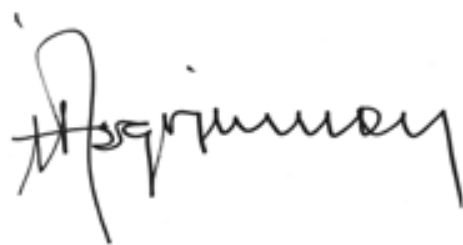

Hálldor Ásgrímsson

Generalsekreterare

Nordiska ministerrådet

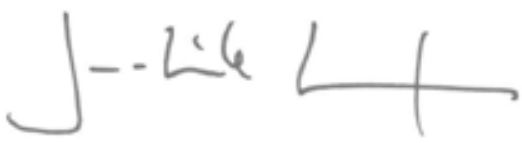

Jan-Erik Enestam

Direktör

Nordiska rådet 


\section{7}

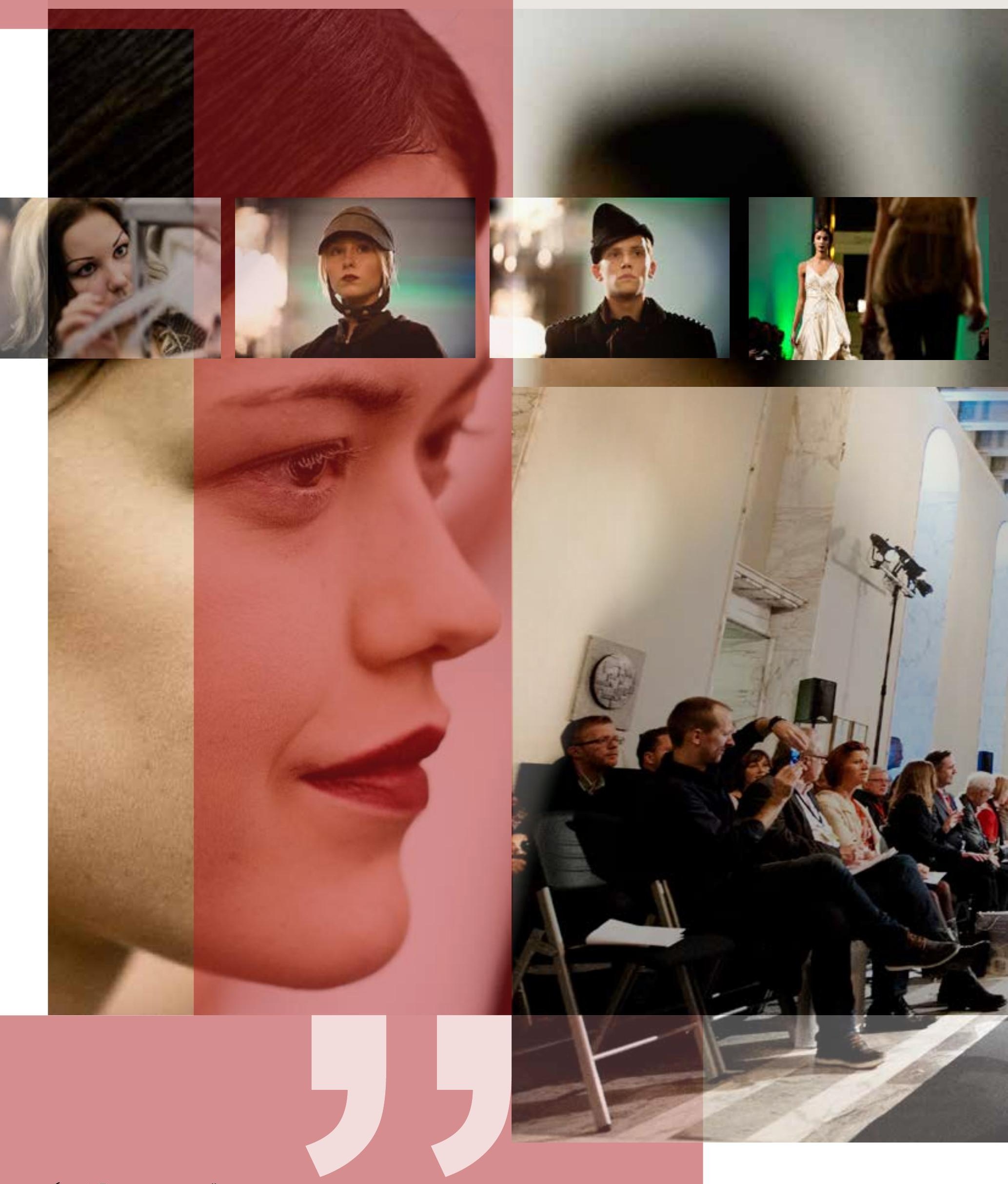




\section{CATWALKEN \\ - en ny arena för nordisk hållbarhetspolitik}

AV HEIDI ORAVA

NÅGRA MODELLER FÅR ACCESSOARERNA LAGDA TILLRÄTTA OCH EN SISTA DUSCH AV HÅRSPRAY INNAN DE GÅR UT PÅ DEN NORDISKA CATWALKEN I FINLANDS RIKSDAG. ALLA BÄR DE KREATIONER SOM TAR STÄLLNING - EN DEL I NYA MATERIAL PRODUCERADE MED HÅLLBARA METODER, ANDRA I ÅTERANVÄNDA TYGER SOM VARKEN GER AVKALL PÅ STIL ELLER KVALITET. DEN NORDISKA HÅLLBARHETSPOLITIKEN HAR ÄNTRAT EN NY ARENA.

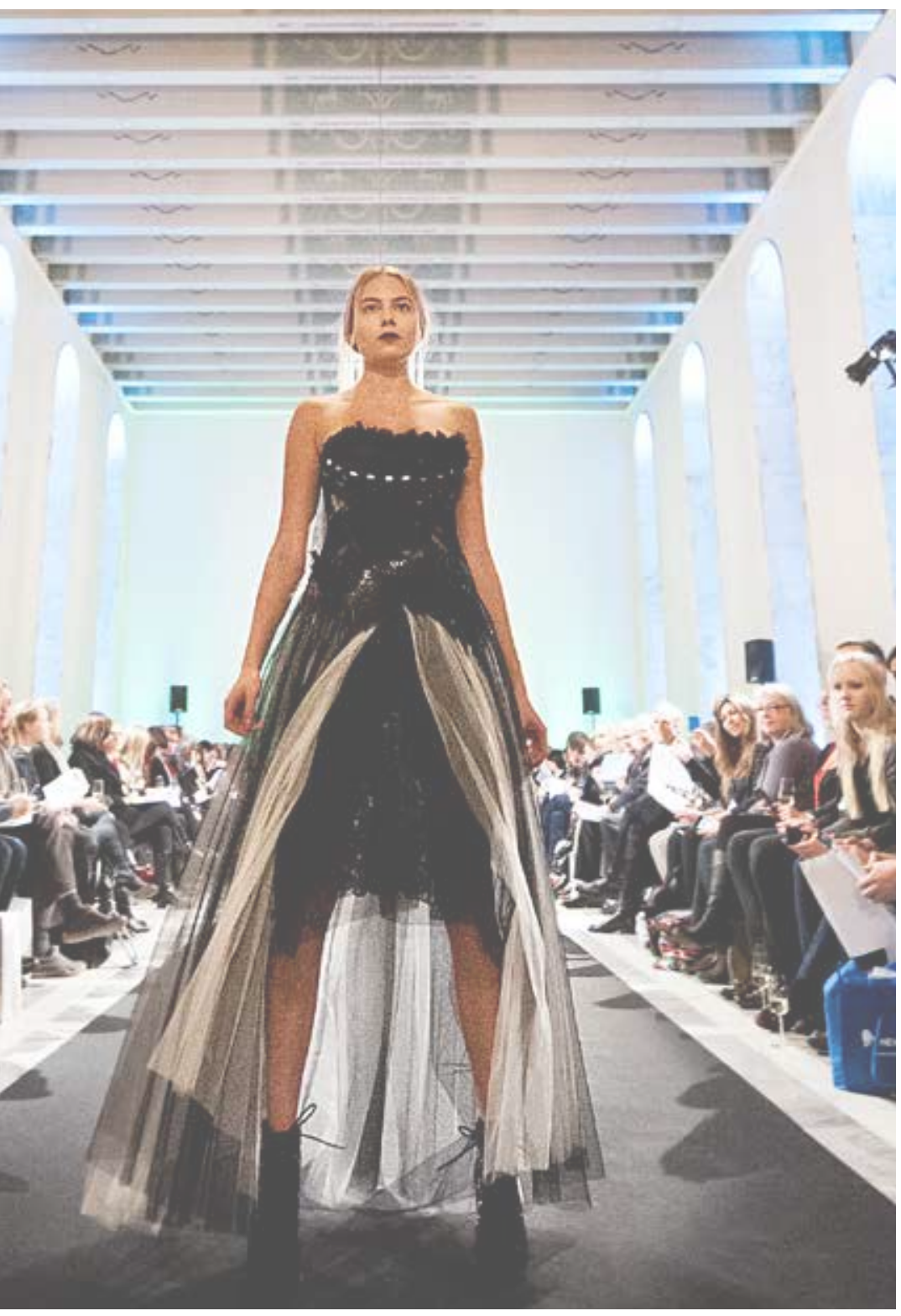

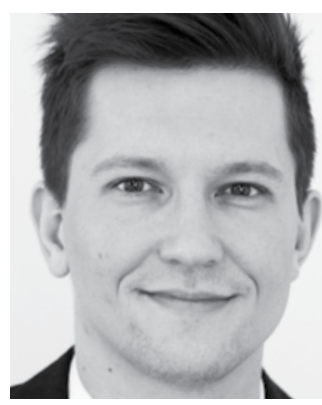

JOHAN ARNø KRYGER

Projektkoodinator

Nordic Fashion Association

(NFA)

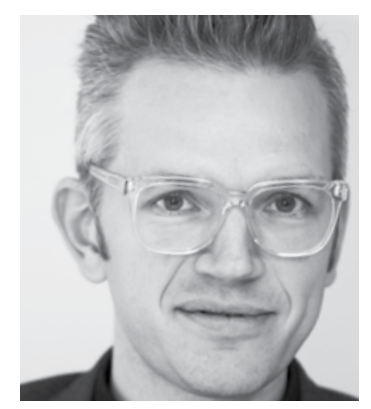

JONAS EDER-HANSEN

Utvecklingsdirektör

Nordic Fashion Association (NFA) $\tau$ publiken sitter politiker, journalister och tjänstemän. Vissa är lätt besvärade av den annars så högtidliga Rikssalens nya utseende - är inte det här lite oseriöst? Men fördomarna kommer snabbt på skam. Plagg efter plagg som svischar förbi manifesterar den hållbarhetspolitik som politiker i hela Norden talar för.

- Om någon bransch kan ändra världen så är det modebranschen, den dikterar vad vi anser om varandra och är kulturbärande utan like. Därför finns det en enorm potential i att låta mode förmedla budskap som går bortom de värderingar som branschen traditionellt förknippas med - hållbarheten är ett utmärkt exempel, 


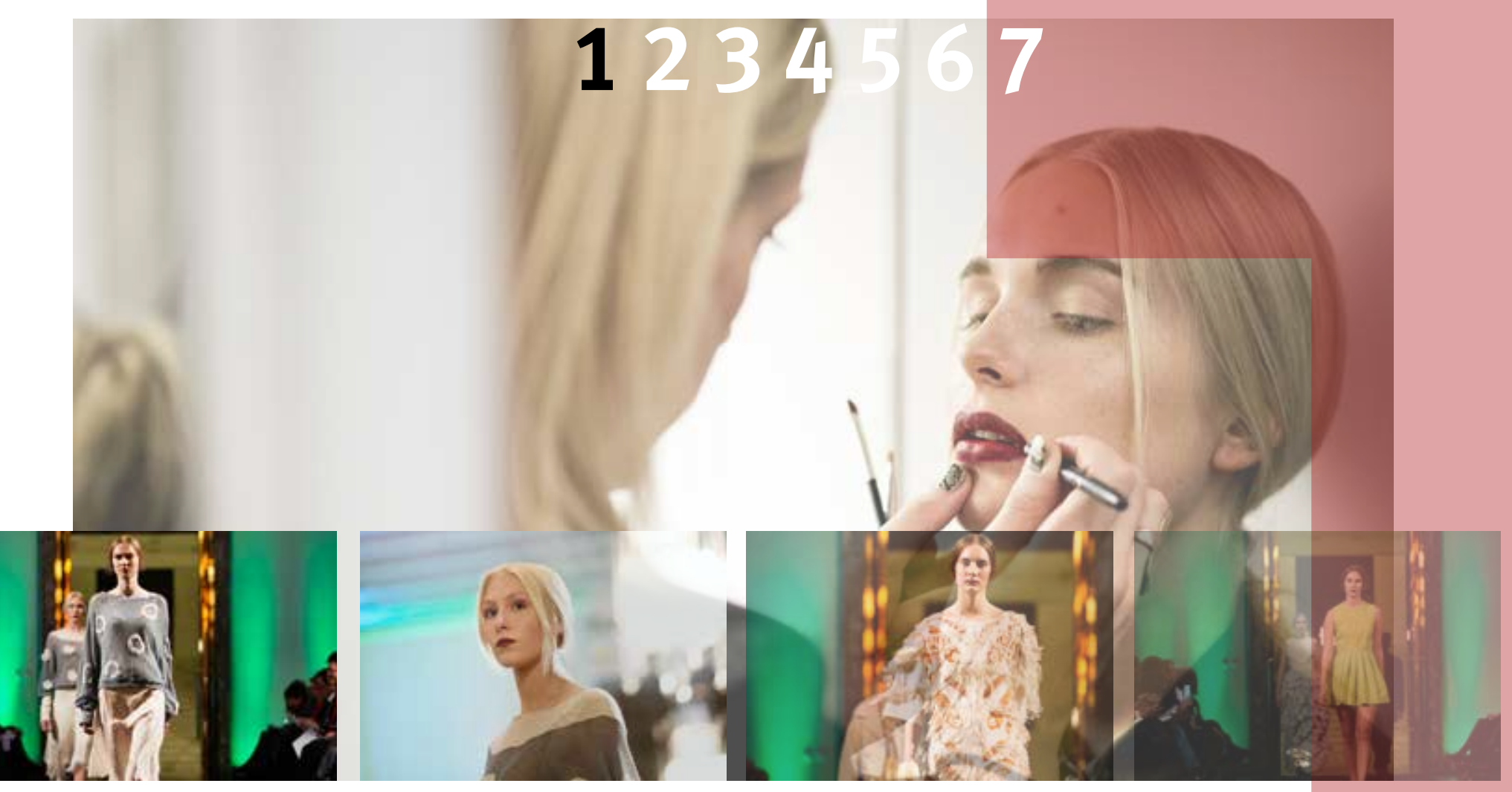

säger Jonas Eder-Hansen, utvecklingsdirektör och en av de eldsjälar som sedan 2008 samlat nordiska aktörer inom hållbart mode till det som i dag är Nordic Fashion Association (NFA).

\section{MEDBORGARINITIATIV MED AVTRYCK}

Den nordiska catwalken i Finlands riksdag är ett evenemang i anknytning till Nordiska rådets session 2012. Upptakten till modeshowen kom som ett medborgarinitiativ. Sedan början av år 2012 har Nordiska rådet erbjudit nordiska medborgare och organisationer möjligheten att lägga fram egna ärenden i Nordiska rådets utskott, och NFA var en av de första att gripa tag i möjligheten.

- Dialogen med Nordiska rådet har varit mycket positiv. Mycket handlar om att finna verksamhetsmodeller som gör det lönsamt att designa hållbart, även för små och mellanstora företag. Verksamheten ska också resultera i god design. På så sätt bidrar vi till en växande industri, säger Johan Arnø Kryger, projektkoordinator på NFA.

Tillväxtpotentialen i hållbart mode blir mycket konkret när Johan Arnø Kryger tar fram en stickad svartvit tunika. Plagget är gjort i en blandning av ull och mjölkprotein, med en silkesmjuk halslinning av enbart mjölkprotein. Bomullstillverkningens ekologiska fotavtryck i kombination med höga bomullspriser har stimulerat produktutvecklingen av textiler som både är miljövänliga, förmånliga att framställa och helt återvinningsbara.
Återvinning av textiler ingår också i ett av de projekt som de nordiska statsministrarna lade grunden för 2011 i initiativet Norden - ledande $i$ grön tillväxt. Jonas Eder-Hansen hänvisar till de studier som Nordiska avfallsgruppen för närvarande låter göra för att finna nya tekniker och metoder för textilhantering.

- Det finns fantastiska möjligheter i återvinning av textiler. Den dag vi i högre grad kan återanvända fibrerna i kläder kommer också mängden textilavfall att minska, säger Eder-Hansen.

- Vi har en kultur i Norden som går ut på att ta vara på varandra och omgivningen. Vi har också en designtradition som är kompatibel med den här dagordningen. Konsumenterna vill varken kompromissa på kvalitet, pris eller design. Därför är vi tvungna att skapa hållbart mode på de här premisserna, och den goda nyheten är att det kan låta sig göras, tillägger Johan Arnø Kryger.

\section{KUNSKAPSLYFT PÅ $3 \times 3 \mathrm{CM}$}

En av utmaningarna i en mer hållbar modebransch är att göra konsumenterna medvetna om konsekvenserna av de egna klädköpen. Ett led i detta är att utnyttja den lilla lappen för tvättinstruktioner bättre, något som NFA kontinuerligt förhandlar om med branschens företag.

Men också branschfolket behöver kunskap. Ett tidigt initiativ inom Nordic Fashion Association var skapandet av en rad gemensamma hållbar- 
hetsspelregler som små och medelstora modeföretag kan förlita sig på när de skaffar leverantörer i utlandet. Dessa presenterades vid Copenhagen Fashion Summit, modetoppmötet som pågick parallellt med COP15-mötet i Köpenhamn 2009.

- Norden upplever ett momentum inom mode och design just nu som vi inte ska låta falla oss ur händerna. Konsumenterna i Beijing och New York köper inte bara plagg, de köper också historien om Norden, den om enkelhet, renhet och hållbarhet. Vi har en nisch med profileringsmöjligheter för hela regionen - och tillväxtmöjligheterna är oändliga, säger Johan Arnø Kryger.
Nordiska rådets möte med Nordic Fashion Association utmynnade i ett utskottsförslag, på danska benämnt Ny Nordisk Mode, som näringsutskottet lade fram vid Nordiska rådets session. Förslaget godkändes i plenum och riktades i form av en rekommendation till Nordiska ministerrådet (se faktaruta).

\section{FAKTA}

- Mode- och textilindustrin är världens tredje största industri och har en årlig omsättning på 2770 miljarder DKK (ca 370 miljarder EUR).

- Till produktionen av en t-tröja används omkring 2500 liter vatten i processen från bomullsfrö till butikshylla. Ett par jeans slukar 3500 liter vatten.

- Industrin kan påverka utsläppen av växthusgaser positivt genom valet av material. Hållbara textiler kan göras av t.ex. bambu, nässlor, tång, skaldjursskal och majs.

- I Norden slänger vi 10-25 kg kläder och textiler per person och år. I genomsnitt har 80 procent av de kasserade kläderna 75 procent kvar av sin användningstid.
Nordiska rådet riktade vid sessionen i Helsingfors en rekommendation till Nordiska ministerrådet om

- $\quad$ att utveckla och igångsätta ett gemensamt nordiskt fortbildningsutbud till designers, verksamhetsutvecklare, inköpare, kommunikations- och butikspersonal

- att igångsätta en koordinerande insats för ett gemensamt nordiskt program för återanvändning av kläder och textilvaror samt

- att utveckla gemensamma exportinitiativ och nya verksamhetsmodeller för Ny Nordisk Mode-initiativet i ett grönt tillväxtperspektiv. 


\title{
2

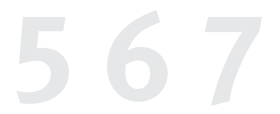

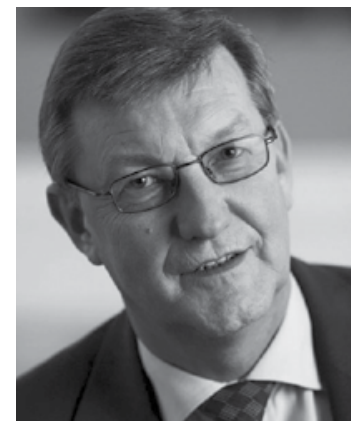

\section{Debatt om}

\section{GRANSHINDER ger ny plattform för det nordiska}

AV ANITA SKOGLUND

\begin{abstract}
I APRIL 2012 GENOMFÖRDES FÖR FÖRSTA GÅNGEN TEMADEBATTER OM GRÄNSHINDER INOM NORDEN I ALLA NORDISKA PARLAMENT. OLE STAVAD, LEDAMOT I GRÄNSHINDERFORUM ÄR MYCKET GLAD ÖVER INITIATIVET OCH NÖJD MED RESULTATET EFTER DEN DANSKA DEBATTEN.
\end{abstract}

- JAG TROR ATT DET ÄR FÖRSTA GÅNGEN PÅ MÅNGA ÅR, SOM JAG HAR VARIT MED, DÅ MAN HAFT DEN NORDISKA DAGSORDNINGEN OCH GRÄNSHINDER SÅ HÖGT PÅ REGERINGENSDAGORDNING. DET NORDISKA HAR FÅTT EN HELT NY PLATTFORM I DANMARK.

$\mathrm{F}$ örslaget om temadebatter väcktes på ett gemensamt möte mellan Nordiska rådets presidium och Gränshinderforum bara några månader innan debatterna faktiskt genomfördes. En av dem som var med på mötet är Ole Stavad från Danmark. Han har tidigare varit både närings- och skatteminister och numera ledamot i Gränshinderforum. Han är glad över temadebatterna och över det fortsatta intresset kring frågan hos det danska folktinget och regeringen.

Inför debatten träffades den danska regeringen och den danska delegation i Nordiska rådet, för att diskutera hur debatten skulle läggas upp och summeras. Regeringen lämnade en redogörelse till Folketinget som innehöll ett antal konkreta problem. Dessa blev grunden för debatten i Folketinget och kunde ingå i ett fortsatt arbete kring gränshinder.

I samband med debatten uppmanade Folketinget den danska regeringen att snarast bjuda in till förhandlingar mellan Folketingets partier om att sluta ett förpliktande avtal kring arbetet med att ta bort gränshinder som hindrar den fria rörligheten för personer och företag inom Norden. Förslaget antogs enhälligt av Folktetinget.

Detta beslut startade en process inom regeringen och i Folketinget och sedan dess har flera möten genomförts för att få till ett konkret avtal. Ole Stavad hoppas på ett avtal i början av 2013. Han menar att detta är det mest konkreta och 


\section{7}

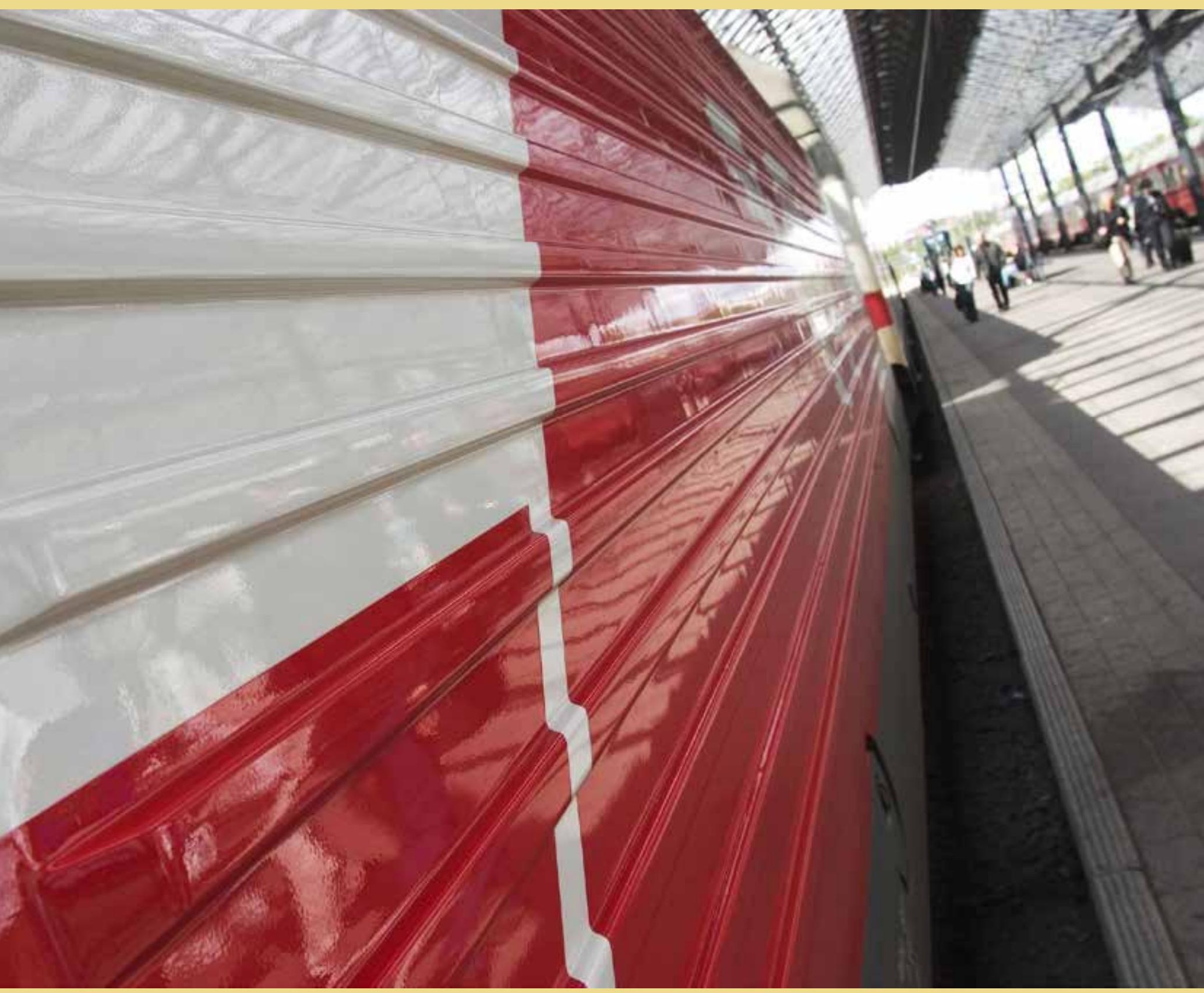




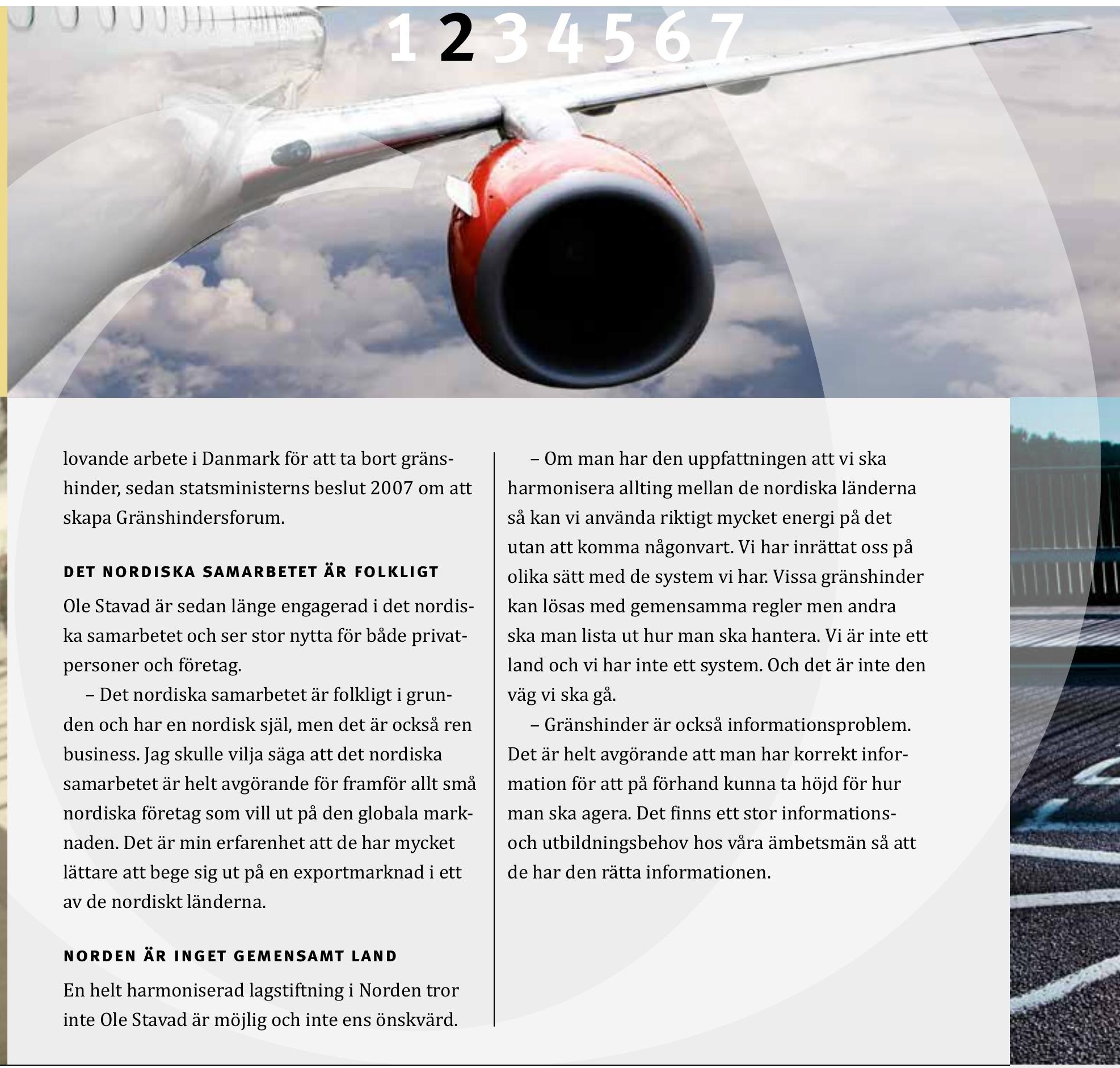

\section{Gränshinder}

Arbetet med att undanröja gränshinder i Norden handlar om att skapa ett öppnare Norden. Det ska vara enkelt att bo eller verka i ett annat nordiskt land. Ingen ska behöva riskera att hamna mellan stolarna eller hindras av oklara lagar och regler i skatt- och socialförsäkringssystem. Men det finns idag gränshinder inom de flesta samhällsområden som försvårar livet för tusentals nordbor och rör arbetskraftens och näringslivets fria rörlighet inom Norden. I april 2012 hölls temadebatter om gränshinder i alla nordiska parlament.

\section{Gränshinderforum}

Gränshinderforum är ett politiskt tillsatt organ, som har fått de nordiska regeringarnas uppdrag att främja den fria rörligheten inom Norden för såväl enskilda som företag. Gränshinderforum ska, i dialog med ländernas regeringar, identifiera, prioritera samt föreslå lösningar på konkreta gränshinder mellan länderna. Forumet består av en representant från vart och ett av de nordiska länderna, inklusive Åland. 


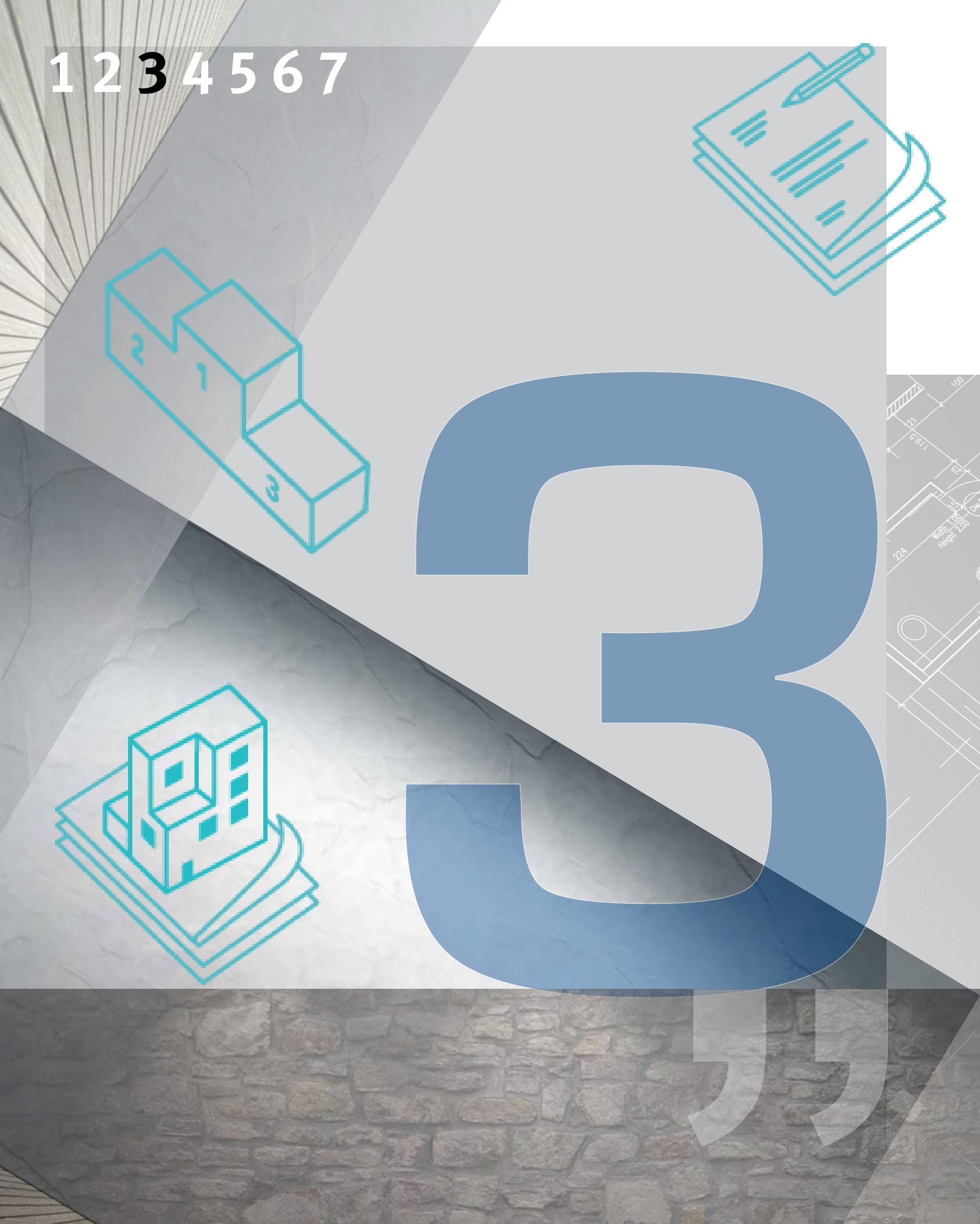

1234567 


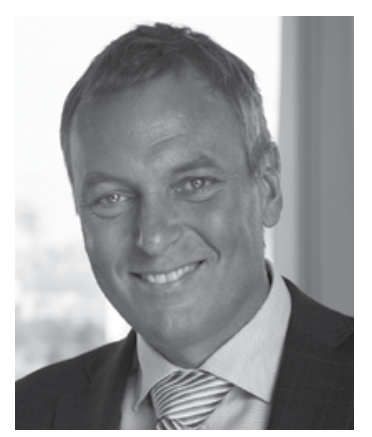

\section{BAREDYGTIG BUSINESS}

- når erhvervslivet udfordrer politikerne

DET KAN BETALE SIG. OG SÅ ER DET GODT FOR MILJ Ø OG MENNESKER. NORDIC BUILT CHARTER SATTER NYE STANDARDER FOR BAREDYGTIGT BYGGERI OG BRINGER BYGGEBRANCHEN FREMAD BÅDE UDE OG HJEMME. MEN POLITIKERE OG REGELVARK HALTER EFTER, MENER LEDENDE KRAFTER I DEN NORDISKE BYGGEBRANCHE.

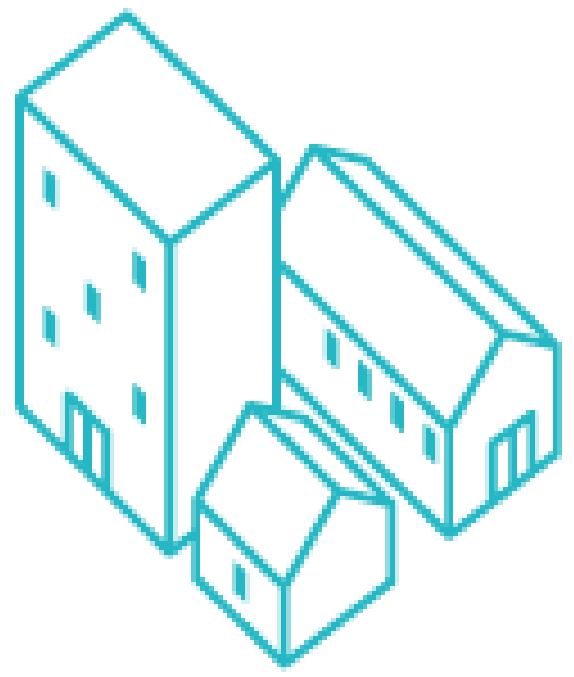

ת n råkold februardag i 2012 var 65 1 topfolk fra den nordiske byggebranche samlet på Schæffergården i København for at diskutere bæredygtigt byggeri. Det skete på opdrag fra Nordisk Ministerråd, som et led i de nordiske landes fælles arbejde for at møde globaliseringens mange udfordringer.

Opgaven var at give et bud på, hvordan Norden kan bidrage til flere klimavenlige byggeløsninger og samtidig styrke de nordiske landes økonomi. Svaret blev Nordic Built Charter, et sæt af principper med fokus på mennesker og miljø - og en målsætning om at tilgodese begge.

Efterfølgende gik Nordic Innovation, en institution under Nordisk Ministerråd, videre med 
opgaven og ved udgangen af 2012 har over 100 virksomheder - lige fra arkitekter og fabrikanter til entreprenører - allerede underskrevet chartret. Kommuner og offentlige myndigheder har også tilsluttet sig og en række af de ledende aktører i den nordiske byggebranche har meldt sig som ambassadører for projektet.

\section{MARKEDET KRAVER DET}

En af disse ambassadører er direktør Rolf Thorsen fra NCC Property Development i Norge. For ham at se, er der ingen modsætning mellem markedskræfter og bæredygtighed, tværtimod: markedet kræver bæredygtige løsninger. Og faktisk halter politikere og regelværk lidt efter, mener han.

- Det offentlige er samfundets største bygherre og lejer. Men politikerne har en tendens til kun at se på den korte bane, når de skal investere. Det koster mere at bygge bæredygtigt. Men det vinder $\mathrm{du}$ ind igen på lavere driftsomkostninger og bedre arbejdsmiljø for de mennesker, som skal bruge byggeriet, mener Thorsen.

Undersøgelser viser, at byggeri, lavet med større hensyn til mennesker og miljø, har en stor effekt på trivslen blandt ansatte i eksempelvis kontorbygninger og institutioner - hvilket i sidste instans har betydning for bundlinjen. $0 \mathrm{~g} ø \mathrm{kono}-$ misk er det også en fordel på andre måder, især i en tid med stigende energipriser.

\section{ET NORDISK BYGGEMARKED}

På spørgsmålet om, hvorfor vi skal samarbejde nordisk om dette, er Rolf Thorsen klar i mælet.

- Hvis vi går sammen om at skabe fælles standarder og tekniske krav på tværs af de nordiske lande, så har vi pludselig et langt større marked. Det kan sikre lavere omkostninger og større lønsomhed for den enkelte virksomhed. De største nordiske entreprenørvirksomheder har allerede afdelinger i alle landene, men for den lille aktør kan dette også gøre en forskel, mener han.

Et populært regneeksempel viser blandt andet, at hvis man samordner kravet til højden på trappetrin i de fem nordiske lande, kan man spare milliarder og åbne nye markeder for en række virksomheder på tværs af grænserne. Og her kunne det offentlige blive en afgørende faktor ved at kræve ikke blot mere ensartede, men også mere bæredygtige standarder.

\section{HOLDNINGER OG VARDIER}

Nordisk Ministerråd har på opfordring af de nordiske statsministre igangsat en række grøn vækst initiativer. Et af dem skal netop se på muligheden for at ensrette tekniske standarder og normer indenfor byggebranchen. Det vil give økonomisk vækst og også flere arbejdspladser - især hvis man bruger det nordiske marked som afsæt til det større globale marked.

\section{Nordic Built Charter}

Vi vil skabe bebyggede omgivelser som:

- Er skabt for mennesker og som fremmer livskvalitet

- Rykker grænserne for bæredygtige aktiviteter, ved brug af vores innovative tankegang og høje vidensniveau

- Forener bylivet med naturens kvaliteter

- $\mathrm{Har} \mathrm{CO}_{2}$-neutral emission i et livscyklusperspektiv

- Er funktionelle, gennemtænkte og æstetisk appellerende og som bygger på det bedste fra den nordiske tradition for design
- Er robuste, holdbare, fleksible og tidløse - bygget med lang holdbarhed

- Udnytter lokale ressourcer og tilpasset lokale forhold

- Produceres og vedligeholdes via partnerskaber, der bygger på et åbent samarbejde på tværs af grænser og fagområder

- Udvikler koncepter som er skalerbare og kan bruges globalt

- Er til gavn for mennesker, virksomheder og miljøet 


\section{3}

Men Nordic Built går længere endnu, det handler også om holdninger.

- Byggebranchen i Norden er på mange måder i front hvad bæredygtighed angår. Dels har vi store udfordringer på grund af vores klima. Men vi har også en kultur og et værdisæt, som gør, at vi kan gå foran på dette område. $0 g$ når vi kan være førende på tekniske løsninger, kan vi også være det på holdninger, siger Rolf Thorsen - eller måske er det ligefrem omvendt?

PÅ FNs bæredygtighedskonference i Rio så man, at erhvervslivet i høj grad presser på for at finde nye bæredygtige veje. Og ifølge NCC direktøren er det en fordel, at vi er så forholdsvis ens i Norden, når vi skal samarbejde om innovative løsninger på tværs af landene.

\section{MOTIVERENDE OG SJOVT}

NCC er ved at bygge nyt domicil i Oslo. Det skal være et såkaldt „passivhus“, som ikke bruger mere energi end det selv generer. Og de ansatte i NCC bliver også motiveret af den udfordring, der ligger i Nordic Built Charter.

- Vore medarbejdere tager virkelig udfordringen op, og vi er blandt andet i gang med at udvikle nye IT løsninger, som skal understøtte den indsats, som Nordic Built Charter lægger op til. Vi er for eksempel ved at udvikle nye 3D projiceringer, som understøtter udviklingen af bæredygtigt byggeri og de nye krav, vi stiller til os selv, fortæller Rolf Thorsen.

Han er overbevist om, at det på sigt er det eneste rigtige også bedriftsøkonomisk. Kravet om bæredygtighed driver både den teknologiske og den forretningsmæssige udvikling. Og så er det sjovt, afslutter direktøren for en af Nordens mange fremsynede virksomheder - som gerne vil have fremsynet politik at bygge på.

\section{Nordic Built Challenge}

Læs også om Nordic Built Challenge, en konkurrence om bæredygtig renovering af fem nordiske bygninger ud fra principperne bag Nordic Built Charter. Renovering af den eksisterende byggemasse regnes som den hurtigste vej mod et mere klimavenligt byggeri - se www.nordicbuilt.org

\section{Nordic Built Ambassadører}

COWI, Energistyrelsen i Danmark, Henning Larsen Architects, KAB, Velux, Batteríid, EFLA Consulting Engineers, Government Construction Contracting Agency i Island, Iceland Green Building Council, Entra Eiendom, NCC Property Development, Snøhetta, Zero, ByggVesta, SINTEF Byggforsk, Pöyry, Uponor and Skanska. 
1.34

4567 


\section{4}

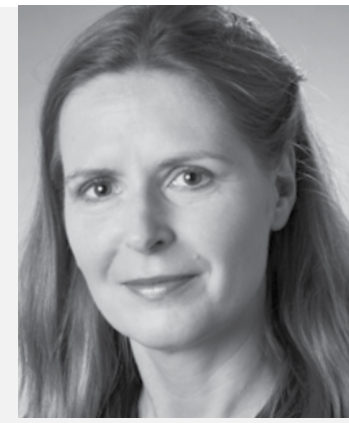

\section{Da BØRNE-}

LITTERATUREN

fik sit blå stempel

AF JESPER SCHOU-KNUDSEN

DER HAVDE VAERT FLERE FORSøG. BÅDE FRA MINISTRE OG FRA PARLAMENTARIKERE. FRA LITTERATER OG LAERDE OG FRA HELT ALMINDELIGE LAESERE. MEN NU SKULLE DET VARE. DEN 31. OKTOBER 2012 VEDTOG PARLAMENTARIKERNE PÅ NORDISK RÅDS SESSION KULTURMINISTRENES FORSLAG OM AT OPRETTE EN HELT NY PRIS: NORDISK RÅDS B ØRNE- OG UNGDOMSLITTERATURPRIS. DET GAV GENLYD. KULTURPOLITISK OG I DET B $\varnothing$ RNELITTERATURGLADE NORDEN.

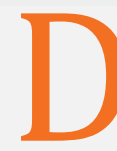
et er nemlig ikke noget, der sker hver dag. Nordisk Råd værner godt om sine priser, der er kun fire af dem, og de er stolte og forbundet med stor prestige. Især Litteraturprisen, der gennem et halvt århundrede har berømmet forfattere, fået oplagstal til at eksplodere og medier til at gå i selvsving. Nu kom der så en femte.

Men hvad er det den skal, prisen, og hvad kan den? Er den andet og mere end forsinket stjernedrys til en trængt litteraturgenre, der - som nogle hævder - er omgærdet af nordisk, nationalromantisk nostalgi sovset ind i Pippi Langstrømpe, Mumitrolde og Gummi Tarzan?
Nina Christensen, Centerleder og lektor fra Center for Børnelitteratur ved Aarhus Universitet i Danmark, er ikke i tvivl om, hvorfor det er vigtigt at vise genren den anerkendelse, som følger med prisen:

- Hvad anerkendelse angår, så er det i min optik så enkelt, at et samfund må anerkende og fremhæve, når nogen yder det ypperste inden for deres område. Her gælder det så vigtigt et område som de tekster, små mennesker møder, samtidig med at de udvikler deres eget sprog. Derfor undrer det mig mere, at der ikke har været en pris før, end at der kommer en pris, fortæller Nina Christensen. 
Da kulturministrene og parlamentarikerne besluttede at oprette en pris for børne- og ungdomslitteratur, fremhævede de fleste netop Pippi Langstrømpe, Mumitroldene eller Karius og Baktus som fyrtårne inden for genren i Norden. Men er det virkelig det bedste, vi kan fremhæve? Nina Christensen er mild i sin reaktion:

- Det er ganske rigtigt tit den ældre litteratur, der fremhæves når man skal nævne genkendelige titler. Det skyldes helt sikkert, at ny børnelitteratur må kæmpe med, at man typisk læser børnelitteratur på tre tidspunkter i sit liv: Når man selv er barn, og når man selv får børn eller børnebørn. Indimellem er der nogle spring på 20-30 år, hvor man som voksen af gode grunde ikke følger med i udviklingen, hvis man ikke arbejder med børn og litteratur, forklarer Nina Christensen. Hun fortsætter:

- Men det kan godt gøre det svært for den ny, aktuelle og måske mere eksperimenterende litteratur at få en plads på bogreolen i hjemmene. Til gengæld lever den i skolerne og på bibliotekerne, så når børn går ud af skolen, vil de typisk have et meget mere aktuelt billede af, hvad børnelitteratur er, end deres forældre har, siger hun.

Uden for Norden vækker den brede politiske opbakning til offentlig kunst- og kulturstøtte opsigt. Men er det overhovedet en politisk opgave - gennem en ny pris - at støtte og markere opbakning til en bestemt - nogle vil sige marginal - genre inden for litteraturen?

- Børn er jo også borgere i Norden og næppe en marginal gruppe. Børn bruger meget tid på at læse både hjemme og i institutioner, og derfor udgives der også hvert år mange børnebøger i de nordiske lande. Så ud fra et markeds-, institutions- eller et brugerperspektiv er børnelitteratur ikke marginal. Men børnelitteratur er i høj grad usynlig i medierne, og det kan en pris forhåbentlig være med til at lave om på, siger Nina Christensen.

Beslutningen om at oprette en ny nordisk pris var enstemmig, og politikerne stod den 31. oktober $\mathrm{i} \emptyset \emptyset$ for at fremhæve det særlige ved nordisk børne- og ungdomslitteratur. Men kan man overhovedet tale om en særlig nordisk tradition inden for børnelitteratur, og hvad kendetegner den $\mathrm{i}$ forhold til andre lande?

- De fleste børn i Norden vil have mødt bl.a. Astrid Lindgren, H.C. Andersen, Tove Jansson og Thorbjørn Egner. Der oversættes også en hel del de nordiske lande imellem, så man kan godt tale om, at der både i historisk og aktuelt perspektiv er en fælles nordisk mængde af tekster til rådighed for børn. Det særlige ved den nordiske børnelitteratur er bl.a. at ny litteratur kan trække på denne tradition - at arven fra den ældre litteratur genfindes i nye tekster, fortæller Nina Christensen.

\section{- Men ligeså vigtigt er det, at man i Norden} har en tradition for at barnet er et selvstændigt individ, der også skal udfordres. Sammenligner man med andre lande er der færre tabuer i den nordiske litteratur og nogle gange en lidt skarpere humor og ironi. Det er i hvert fald sådanne reaktioner jeg hører, når jeg og mine kolleger taler om nordisk litteratur i internationale sammenhænge, siger hun.

Da det blå stempel fandt vej til børnelitteraturen i efteråret, var politikerne enige om, at man 
samtidigt fik et værn mod massekulturen udefra. Også selvom Facebook, computerspil og Youtube for længst har sneget sig ind under og over dynen i de nordiske børneværelser og fortrængt bogen som børn og unges foretrukne dannelsesmedie.

Men hvad med min egen datter på 6 år, som lige nu gladere for computerspil og tyske eventyr end fortællinger af moderne børnebogsforfattere. Har hun bare dårlig smag, eller er alternativerne for usynlige? Vil en ny pris kunne være med til at dæmme op for den kommercielle (især amerikanske) massekultur? Vi hører igen Nina Christensen fra Center for Børnelitteratur i Danmark:

- Børn har i dag adgang til fortællinger i rigtig mange former og tit er der jo et samspil mellem $\mathrm{fx}$ bøger, film og computerspil. Det vigtige er, at børn har adgang til en vifte af forskellige former for udtryk, så de kan være med til at danne og udvikle deres egen smag. Der er jo fx stor forskel mellem Brødrene Grimm og det sproglige univers, din dat- ter møder i et computerspil. For mig peger det på, at også børn er nysgerrige individer, der har stor appetit på mange forskellige ting, forklarer hun.

Nina Christensen understreger dog, at det ikke er gjort med at give en pris:

- Men computerspil, film og store kommercielle satsninger har et marketingsbudget, som ingen nyudgiven nordisk børnebog kan konkurrere med. Derfor er prisens succes også afhængig af, om prisen bliver formidlet bredt ud. Når forfatteren Jacob Martin Strid får Kronprinsparrets Pris på 500.000 kr., er der liveshow i den bedste sendetid og massiv mediedækning. Man kunne ønske sig at børnelitteraturprisen - og de øvrige priser i nordisk regi - fik en lignende opmærksomhed og opfølgning, slutter Nina Christensen.

\section{FAKTA}

Den 31. oktober 2012 besluttede Nordisk Råd under sessionen i Helsingfors at oprette helt ny pris for børne- og ungdomslitteratur. Prisen bliver uafhængig af Nordisk Råds prestigefyldte Litteraturpris.

Nordisk Råds Litteraturpris for børne- og ungdomslitteratur er på 350.000 danske kroner og uddeles sammen med Nordisk Råds andre priser for litteratur, musik, film og miljøarbejde på Nordisk Råds årlige session 


\section{5}
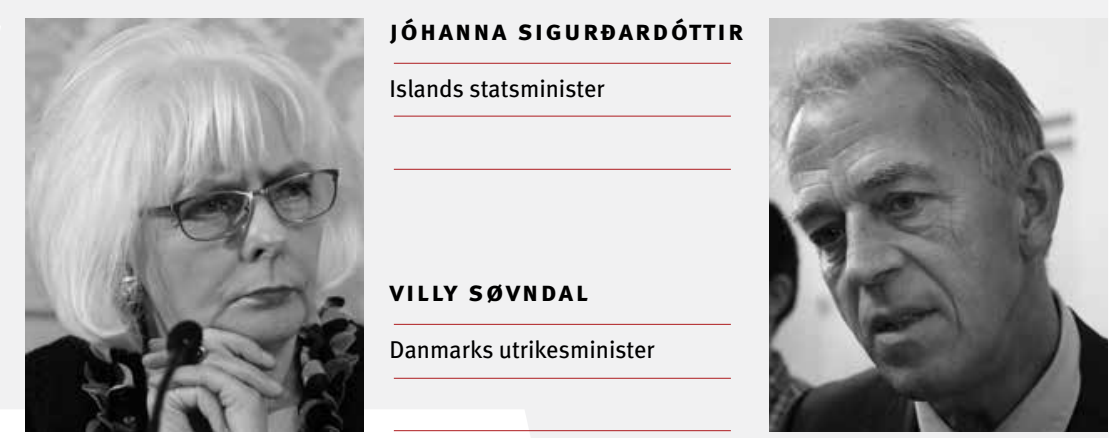

\section{Påträngande OMVÄRLD skapar nordisk enighet}

AV KARIN ARVIDSSON OCH JESPER SCHOU-KNUDSEN

DET HAR SETTS SOM ETT AV DE STÖRSTA MISSLYCKANDENA I DET NORDISKA SAMARBE-

TETS HISTORIA. NORDISK UTRIKES-, FÖRSVARS- OCH SÄKERHETSPOLITIK HAR ALDRIG FÅTT POLITISKT GENOMSLAG OCH LÄNDERNA HAR DRAGIT ÅT OLIKA HÅLL. NORDEN HAR SLITITS I DELAR MELLAN SOVJET OCH USA OCH INTE FÖRMÅTT HÅLLA IHOP.

$\mathrm{F}$ ram till idag. Nu sitter alla i samma båt rent bokstavligt. På Hurtigruten i en norsk fjord sommaren 2012 sitter de nordiska statsministrarna och är alla eniga: den nordiska försvars- och säkerhetspolitiken har aldrig varit tätare än nu, och ska förstärkas ytterligare. Men det betyder inte att frågorna lyfts in i Nordiska rådet och Nordiska ministerrådet, bara att viljan finns och att arbetet drivs framåt. Klimatförändringar, USA:s nedläggning av NATO-basen på Island och bristande ekonomiska resurser gör det omöjliga möjligt. Norden har mer än någonsin att vinna på att agera som en samlad kraft internationellt.

Samarbetet inom utrikes- säkerhets- och försvarspolitik mellan de nordiska länderna har under de senaste åren fördjupats, både vad gäller konkreta handlingar och ambitioner. Trots att dessa frågor inte är del av det officiella nordiska samarbetet, har frågorna diskuterats intensivt av ministrar och parlamentariker inom samarbetet och lett till flera konkreta åtgärder.
Försvarssamarbetet intensifierades med inrättandet av paraplyorganisationen NORDEFCO 2009. Där arbetar försvarsmakterna tillsammans inom områden som logistik, utbildning, operativ verksamhet och internationella insatser. Samarbetet mellan de nordiska länderna har fătt en nyckelroll i de utmaningar som de nordiska försvaren ställts inför efter de stora nedskärningar som genomförts i Norden sedan kalla krigets slut.

\section{ARKTIS VIKTIGT}

Klimatförändringarna har gjort Arktis till en av vår tids viktigaste geopolitiska frågor. Här finns mycket att vinna på ett gemensamt nordiskt agerande för att säkra både den unika naturen och den arktiska befolkningens sociala och kulturella utveckling. Dessutom kan smältande polarisar komma att helt rita om den militärstrategiska kartan.

En annan omvärldsförändring som lett till ett mer integrerat Norden finns på Island, som är ett av få länder i världen som inte har något eget 


\section{5}

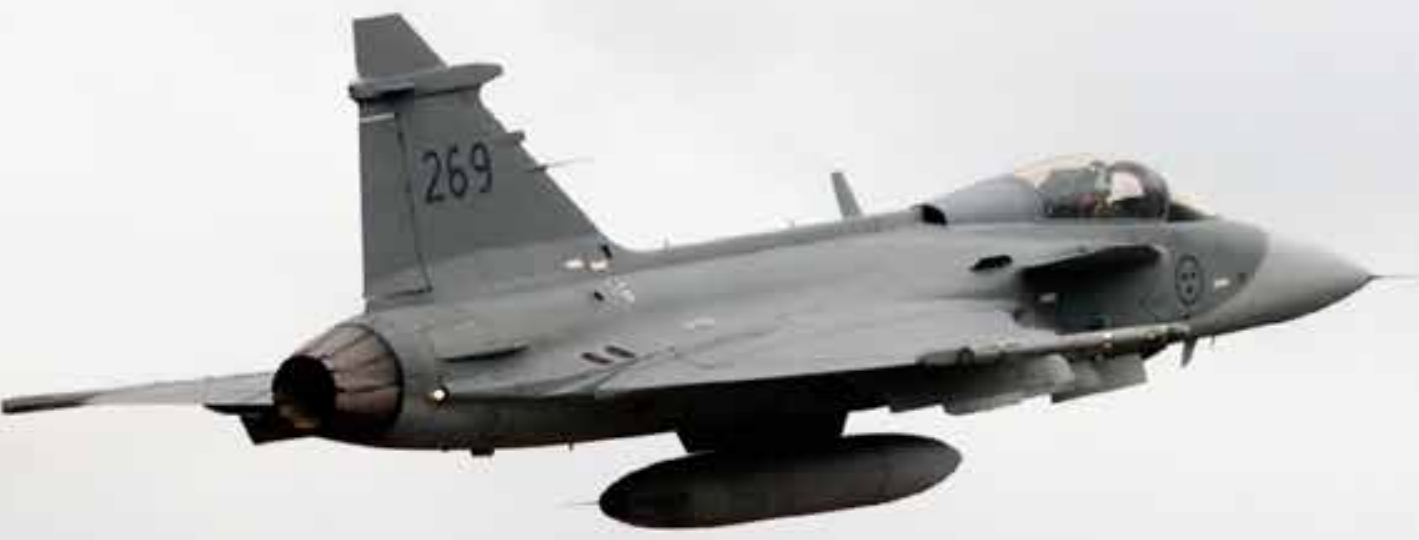

\section{FAKTA}

Idén om ett starkt nordiskt försvarssamarbete kan spåras tillbaka till 1800-talet. Efter andra världskriget fanns intensiva diskussioner om bildandet av en nordisk försvarsunion, men detta föll, delvis på grund av att Danmark, Norge och Island valde att gå med i NATO vid bildandet 1949. Under kalla kriget fanns det lite utrymme för nordiskt försvarssamarbete i skuggan av NATO och Warzawapakten. Engagemanget för samarbete har sedan kalla krigets slut ökat och när den nordiska paraplyorganisationen NORDEFCO upprättades 2009 var det en milstolpe. Här samarbetar de nordiska försvaren inom en lång rad områden som logistik, utbildning, operativ verksamhet och internationella insatser. Finland och Sveriges statsministrar deklarerade i år att man kommer att hjälpa Norge med luftövervakningen av Island från 2014. 
försvar, och därmed saknar övervakning av luftrummet. USA avsade sig uppgiften efter att ha lagt ner sin militärbas i Keflavík 2006, sedan dess har uppgiften temporärt skötts av Norge. I oktober i år deklarerade de svenska och finska statsministrarna att denna uppgift ska skötas gemensamt från 2014.

- Det gläder mig därför mycket att processen har nått så långt i frågan om gemensam luftövervakning av Island - även jag tycker att det är en naturlig fortsättning på det nordiska samarbetet, kommenterade Jóhanna Sigurðardóttir Islands statsminister, beslutet.

\section{DRIVKRAFTERNA FÖRÄNDRAS}

Nordiska rådet har sedan en tid arbetat för ett nästa steg i utrikes- och försvarssamarbetet medan de nordiska ministrarna än så länge är mer kritiska till en sådan tanke.

- Vi behöver inga nya överbyggnader för att med gemensamma krafter stärka Nordens roll i omvärlden, säger Danmarks utrikesminister Villy Søvndal.

Framförallt för att det i dagsläget fungerar så bra att man är rädd att en formalisering skulle komplicera och försvåra arbetet. Men tveksamheten finns också i historiens skugga - ett formaliserat försvarssamarbete kan även efter kalla krigets slut vara politiskt kontroversiellt.

En som också talar sig varm för en formalisering är forskaren Johan Strang, som diskuterar just detta i Nordiska rådets jubileumsbok 2012, Nordiska Gemenskaper. Boken är till dels en uppföljning av den uppmärksammade Stoltenberg- rapporten 2009. Strang menar att en formalisering är nödvändig för att försvarssamarbetet ska kunna ta nästa steg, och att utrikes- och försvarspolitiken spelar en nyckelroll för utvecklingen av det nordiska samarbetet. Detta, kan kopplas till att drivkrafterna bakom nordiskt samarbete har förändrats, enligt Strang som arbetar vid CENS, Centrum för Norden-studier i Helsingfors.

\section{OMVÄRLDEN AVGÖR}

- Då det officiella samarbetet etablerades på 50och 70-talen var det i första hand en fråga om att skapa ett välfungerande samarbete inom Norden. Idag handlar samarbetet i stigande grad om Nordens förhållande till sin omvärld, säger Strang i boken.

Det är viktigt att Norden kan agera enat i internationella frågor inom organ som exempelvis EU, FN och Arktiska rådet. Att detta arbete idag sker utanför de formella ramarna har försvårat utformandet av en gemensam politik, enligt Johan Strang.

Formalisering eller inte. Sista ordet är ännu inte sagt. Men det står dock helt klart att nordisk utrikes-, försvars- och säkerhetspolitik, som så länge betraktats som en anomali, nu träder fram ur skuggorna och tar form. Gemensamt försvar, samägda ambassader, kollektiva vapeninköp, ömsesidig solidaritet eller unison kamp mot klimatpåverkan - arbetsinsatserna kan vara många. En påträngande omvärld skapar nordisk enighet. 


\begin{abstract}
6
Inte längre OFFER

AV BODIL TINGSBY

MATS, BIRGIT OCH SHABANA ÄR NAMNEN

PÅ TRE KÄNDISAR SOM DROG STORPUBLIK

TILL DEN NORDISKA MONTERN PÅ 2012 ÅRS

BOKMÄSSA I GÖTEBORG. ATT TVÅ AV DEM

HAR FUNKTIONSHINDER OCH EN TILLHÖR EN

INVANDRARFAMILJ ÄR INTE ANLEDNINGEN

TILL DERAS KÄNDISSKAP. INTE NU LÄNGRE.

MEN DET VAR SÅ DET BÖRJADE. LÅT OSS TA

DERAS LIVS HISTORIER I KORTVERSION.
\end{abstract}

ats Melin var innerligen trött på att hugga ved och blev glad när ledaren Pär Johansson undrade om Hudiksvalls kommun i norra Sverige inte kunde byta ut vedhuggningen mot teater som aktivitet för de funktionshindrade. Så bildades Glada Hudikteatern, och resten är historia. Efter spel för fulla hus i hemstaden gick färden till Stockholm, till tevepubliken och sen till Broadway.

Nästa föreställning blir Trollkarlen från $\mathrm{Oz}$, och Mats berättar att han ska spela hund. Sen sin trevande start på tiljorna i Hudik har han också som en av rollfigurerna i matkedjan ICA:s uppmärk-
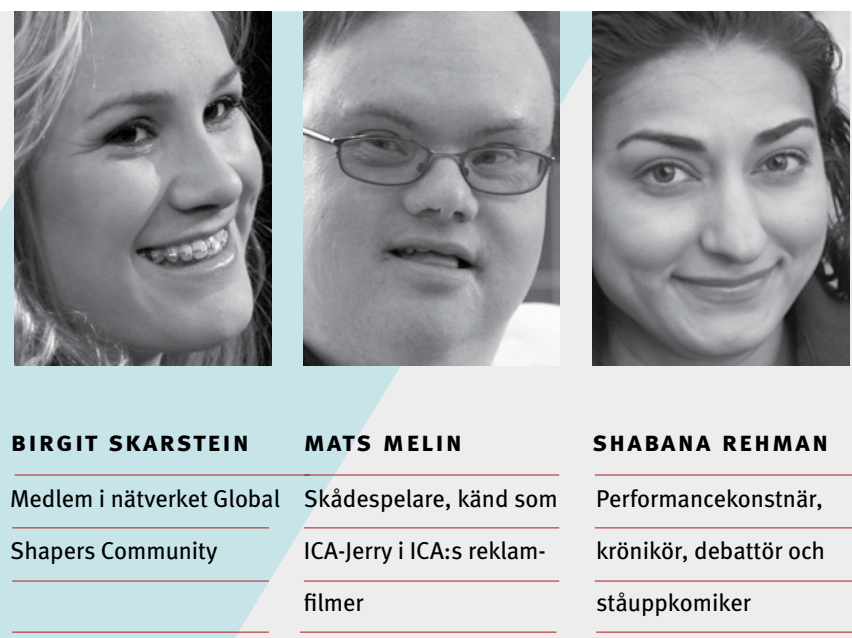

SHABANA REHMAN

Performancekonstnär,

krönikör, debattör och

ståuppkomiker sammade reklamfilmer blivit ICA-Jerry med hela svenska folket.

- Megakändis, säger han och talar med förnöjsam min om att han gillar all uppmärksamhet.

Birgit Skarstein var 19 år när hon råkade ut för en olycka som gjorde henne förlamad från midjan och ned. Nu är hon bland annat en av World Economic Forums enastående unga människor i nätverket The Global Shapers Community. Alltså en av de som anses kunna påverka samhällsutvecklingen allra mest i sin del av världen. Som gäst i det norsk-svenska teveprogrammet Skavlan berättade hon att hon studerar statsvetenskap för att kunna 


\section{7}
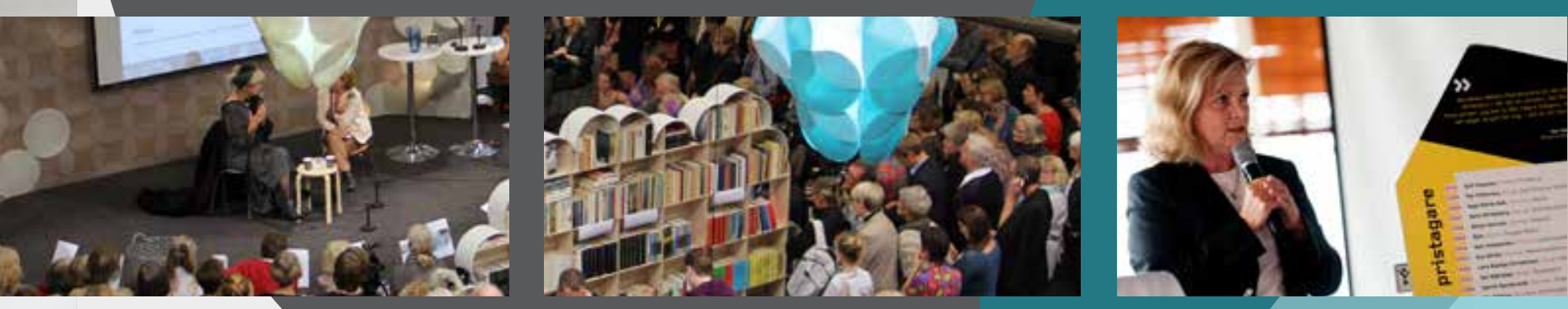

bli statsråd. Varför inte statsminister, undrade Skavlan.

Birgits väg till kändisskap gick via teveprogrammet Ingen grenser, som är den norska varianten av konceptet där funktionshindrade tävlar om att ta sig igenom en strapatsrik del av Afrika.

- Men det var inte för att bli kändis som jag ställde upp, säger Birgit. Här erbjöds jag äntligen en chans att på mina villkor framstå som en ung och stark människa. Ingen utställning av funktionshindrade, eller funkis, som hon väljer att säga, ingen offerroll till "tårevåt" musik utan rätt och slätt ett utmanande uppdrag om att ta sig från A till B.

Som alla andra i sin generation lekte Shabana Rehman Pippi eller Ronja Rövardotter eller Mormor og de åtte ungene i byen när hon var liten.

- Men jag såg ju inte ut som de nordiska barnbokshjältinnorna. Jag var så mörk i hyn när jag föddes att till och med min pakistanska familj förskräcktes och gav mig öknamnet Kali. Svartskalle.
Mormor grät när Shabana föddes inför tanken på hur svårt det skulle bli att gifta bort henne, men pappa tröstade och berättade att Kali är en vacker, självständig, kärleksfull och vältalig hinduisk gudinna.

- Och det är så vi känner henne i Norge, som en provokatör som visserligen fokuserar på integrations- och mångfaldsfrågor men som framförallt är en enastående performancekonstnär, programledare och dramatiker, sa statssekreteraren i det norska kulturdepartementet, Kersti Stenseng, när hon presenterade Shabana på bokmässans nordiska scen.

Genom att i femtio år i rad dela ut Nordiska rådets litteraturpris har det nordiska samarbetet bidragit till lika många framstående nordiska författares framgång. Självklart var det en orsak till att Nordiska ministerrådet och Nordiska rådet ställde upp som huvudtema på Nordens största bokmässa 2012. Men vi hade större ambitioner 



\section{7}
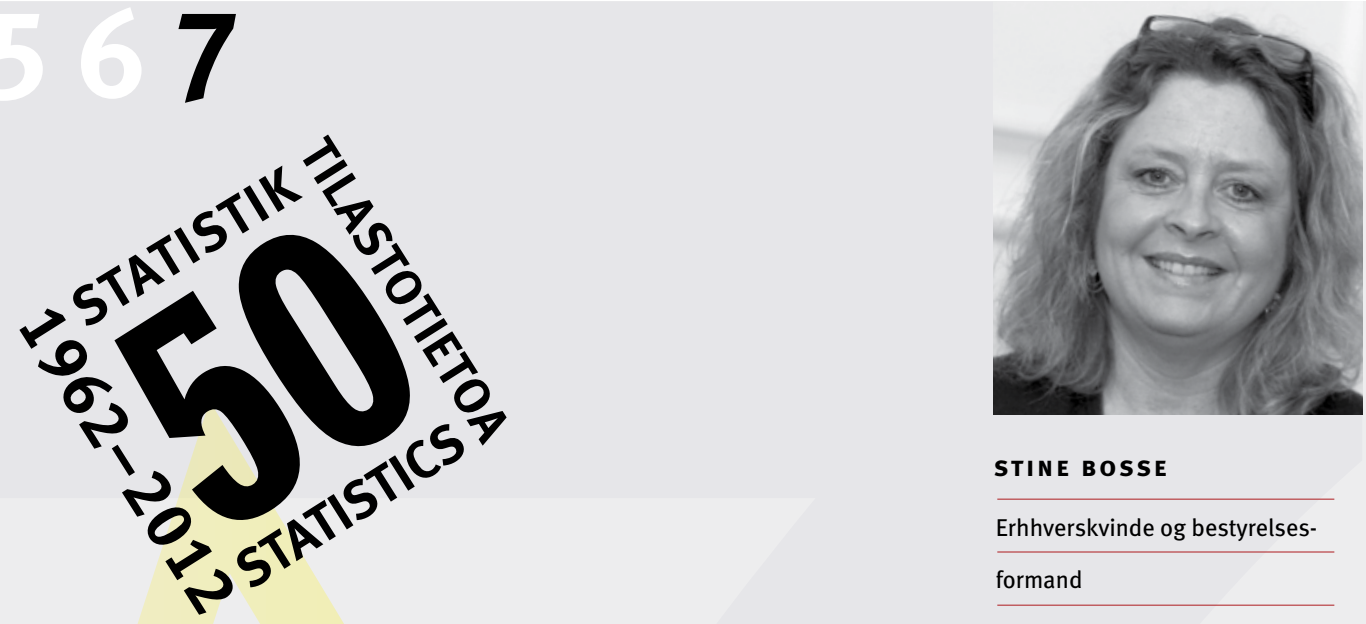

STINE BOSSE

Erhhverskvinde og bestyrelses-

formand

\section{Tørre men tanke- vækkende TAL}

AF LOUISE HAGEMANN

ANLEDNINGEN VAR NYE TAL FRA NORDISK STATISTISK ÅRBOG 2012 OG ET TILBAGEBLIK PÅ DE SIDSTE 50 ÅR MED STATISTIK FRA HELE NORDEN. EN FLOK UNGE STUDERENDE FORLOD DET FINE, GAMLE AUDITORIUM, ALEXANDERSALEN, PÅ KØBENHAVNS UNIVERSITET OG OVERLOD STOLENE TIL OS. NU VAR DET VORES TUR TIL AT HØRE OM GINI-KOEFFICIENTEN OG BNP, MEN VI GIK DERFRA MED HOVEDET FULDT AF SPØRGSMÅL OM, HVILKET SAMFUND, VI ØNSKER VORES BØRN SKAL VOKSE OP I.

$\mathrm{T}$ allene taler deres tydelige sprog om den enorme udvikling, som de nordiske lande har gennemgået de sidste 50 år. Tendenser, som nu lægger et massivt pres på vores økonomi og den nordiske velfærdsmodel.

\section{SKATTERNES ANDEL AF BNP ER STEGET \\ FRA 20-30 \% FRA BEGYNDELSEN AF \\ 1960'ERNE OG TIL 36-48 \% I DAG.}

Professor Christian Hjorth-Andersen tog udgangspunkt i den voldsomme stigning i skatterne.

- Da jeg studerede i 1960'erne var der en livlig diskussion om hvorvidt vores samfund ville bryde sammen, hvis skatternes andel af BNP oversteg 25 $\%$ - det var det magiske tal, siger professoren og konstaterer med et smil på læben, at det jo ikke skete.

Nej vores samfund er heldigvis ikke brudt sammen, men erhvervskvinden Stine Bosse er tydelig bekymret over udviklingen - og også lidt bitter.

Fra 2003-2005 sad hun i Velfærdskommissionen, som i deres rapport til den danske regering klart tilkendegav, at det var tvingende nødvendigt at gribe ind med reformer. Men anbefalingen blev blot afvist som et forkert og fordrejet billede af, hvordan verden så ud, konstaterer Stine Bosse tørt.

- Hvis man havde taget disse statistikker alvorligt og fået øjnene op for de tendenser, som virkelig presser os nu, så kunne man have grebet ind noget før. Så var vi selvfølgelig gået glip af en sjov fest, men det var fuldstændigt uansvarligt, understreger Stine Bosse.

Men så kom Finanskrisen, og nu har Danmark også indført reformer for at tilpasse velfærdsmodellen til den økonomiske krise. Stine Bosse er dog ikke et sekund i tvivl om, at modellen bare skal justeres:

- Når vi ser på disse tal og tendenser og bliver forskrækkede, så må vi ikke blive så bange og tro at 


\section{7}

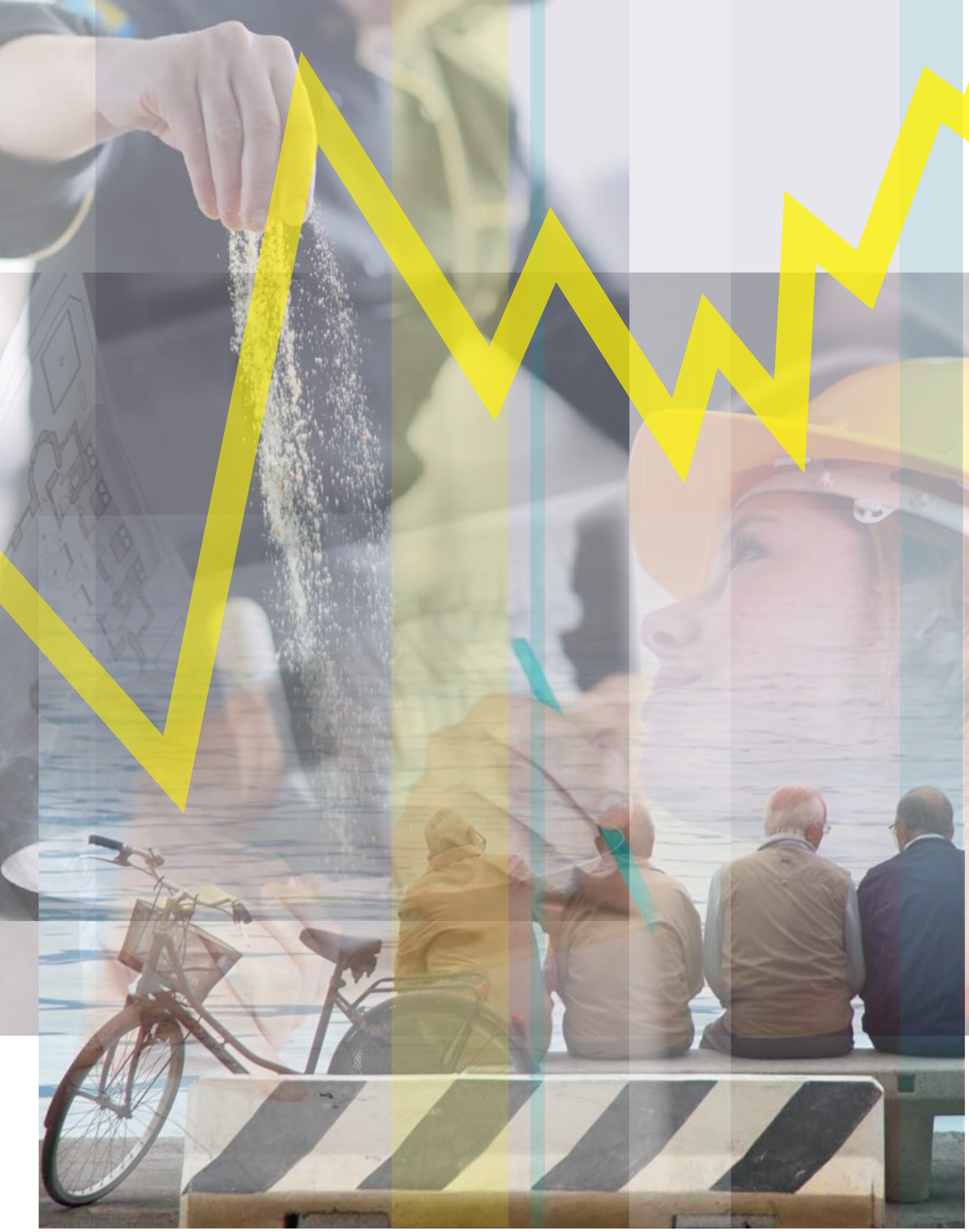


vores model ikke fungerer. Jeg er inderligt overbevist om, at den nordiske model, hvor vi har høj grad af lighed og distribueret velfærd, holder vand.

\section{KVINDER I NORDEN KAN FORVENTE AT BLIVE 83 ÅR GAMLE NU MOD 74 ÅR I BEGYNDELSEN AF 60'ERNE.}

Set på tværs af de mange tusinde tal i Nordisk Statistisk Årbog fremhæver professoren den måske største trussel mod velfærdsmodellen:

- Befolkningen bliver markant ældre nu og det er en dramatisk udvikling, som er fælles for alle de nordiske lande, siger Christian Hjorth-Andersen.

Stine Bosse kalder det „den gode nyhed“, at vi nu lever så meget længere. Men erhvervskvinden, der stod i spidsen for Tryg og nu sidder i bestyrelsen for bl.a. Nordea og TDC, mener også, at det er nødvendigt at tænke i en ny arbejdsdeling mellem det offentlige og private.

- Når vi bliver så gamle, skal vi jo have skiftet knæ og hofter ud. Når staten ikke længere kan bære de stigende sundhedsudgifter, kunne man lave en ordning, hvor vi alle sammen sparer op til den slags operationer. Men hvis man falder udenfor arbejdsmarkedet, må det offentlige tage over i en periode, så alle kan blive hjulpet. Vi skal lave reformer og tage nye metoder i brug, men samtidig holde skarpt øje med, hvorfor det er så dejligt at være i Norden i forhold til andre lande, mener Bosse.
I 1960 VAR DER 2 MIO. BILER I NORDEN, I 2011 VAR DER 12 MIO. ELLER NASTEN ÉN BIL FOR HVER 2. INDBYGGER.

Men for Stine Bosse, som også er bestyrelsesformand for Børnefonden og den grønne tænketank CONCITO, er krisen blot et midlertidigt økonomisk problem. Hun er langt mere optaget af, at vi făr skabt en vision for vores fremtidige samfund. Det handler blandt andet om i et respektfuldt samarbejde med det grønlandske selvstyre at udnytte råstofferne i Grønland før kineserne gør det og blive dygtige til at tackle klimaudfordringerne og den grønne omstilling.

- Vi har en kæmpe forpligtelse til at give vores børn og unge et perspektiv om et liv, som er bedre end vores. Hvis man tager til Afrika, Asien og Sydamerika, så er unge overbevist om, at de får et liv, der er bedre end deres forældres og bedsteforældres. Men vi kan ikke jo ikke sige til vores børn, at de skal stræbe efter at have 3 biler eller rejse på ferie 4 gange om året. Vi er nødt til at give dem noget nyt - et nyt perspektiv og mening med livet. Jeg kan ikke svarene, men spørgsmålene står og blinker til os alle sammen, slår hun fast.

Selvom Sverige klarer sig bedst i øjeblikket, så er alle de nordiske lande „på toppen“ i Europa, som Bosse så passende beskriver det. Derfor har vi i Norden en særlig forpligtelse til at gå forrest og at skabe den nye og visionære vej for Europa, lyder Stine Bosses klare opfordring afslutningsvis til os i Alexandersalen og alle andre!

\section{Nordisk Statistisk Årbog}

Der er indsamlet og udgivet statistik i Norden siden 1962. Få et unikt indblik i udviklingen i Norden gennem de sidste 50 år

www.norden.org/tema/nordisk-statistik-i-50-aar

\section{Stine Bosse}

- Født 1960, og uddannet cand. Jur.

- Group CEO i TrygVesta A/S 2001-2011.

- Bestyrelsesformand i Flügger Denmark, Det Kongelige Teater, CONCITO, Børnefonden, og Copenhagen Art Festival og sidder i bestyrelsen i bl.a. Nordea Bank A/S, TDC, Allianz og Aker ASA.

- I foråret 2010 blev hun udnævnt til Advocate for the Millenium Development Goals af FNs Generalsekretær, Ban Ki-moon, i kampen mod sult og fattigdom. 

Nordiska ministerrådet Nordiska rådet

Ved Stranden 18

DK-1061 København K

www.norden.org 